\title{
Cultural similarities and housing market linkage: evidence from OECD countries
}

\author{
Weida Kuang ${ }^{*}$ and Qilin Wang
}

\author{
* Correspondence: kuangweida@ \\ rbs.ruc.edu.cn \\ Department of Finance, School of \\ Business, Renmin University of \\ China (RUC), 59 Zhongguancun \\ Street, Haidian District, Beijing \\ 100872, People's Republic of China
}

\begin{abstract}
The subprime crisis provoked a growing study on international housing market linkage. Nevertheless, the extant literature fails to explore housing price co-movements in terms of culture and a country's responses (e.g. housing market conditions and government participation). Employing the databases on cultural similarities, housing market conditions and government participation in 18 OECD countries over 1970-2016, this article suggests that culture similarities affect house price co-movements via information dissemination efficiency and investment conduct consistency. In addition, housing supply elasticity and government participation are able to mitigate house price contagion. Hence, to withstand external shocks, countries should pay attention to the role of cultural similarities in housing price interdependence. Moreover, it is necessary to ensure that housing supply is resilient and improve government participation.
\end{abstract}

Keywords: Cultural similarity, House price linkage, Housing supply elasticity, Government participation

\section{Introduction}

\section{Background}

The 2008 subprime mortgage crisis triggered by the plummeting of housing prices in the United States not only evolved into a global economic crisis, but also gave rise to worldwide housing market contagion (Hoesli and Reka 2013; Milunovich and Trück 2013). As shown in Fig. 1, housing prices in the US, the source of the 2008 financial crisis, declined substantially between 2007 and 2012, with a remarkable fall in prices of $9.5 \%$ in 2008. Similarly, housing prices in Canada, Japan and the United Kingdom fell in 2009 by 2.7, 6.1 and 7.9\%, respectively. ${ }^{1}$ Nevertheless, it appears that housing prices in Germany and Australia were unaffected by the global economic crisis. Yu (2010) examined the housing systems of 18 OECD countries and found that liberal housing market patterns represented by the US and the UK are market-dominated and more subject to housing price shocks. By contrast, continental law countries such as Germany and France, which combine market mechanisms with public intervention, are more capable of resisting external shocks. Unfortunately, previous research neglects the responses of an affected country to a country that was the source of the contagion. In theory, the responses of a country to housing price shocks are determined by that country's housing market conditions and housing security system. In other words, the responses of a particular country decide its capability to withstand external shocks

(c) The Author(s). 2018 Open Access This article is distributed under the terms of the Creative Commons Attribution 4.0 International License (http://creativecommons.org/licenses/by/4.0/), which permits unrestricted use, distribution, and reproduction in any medium, provided you give appropriate credit to the original author(s) and the source, provide a link to the Creative Commons license, and indicate if changes were made. 


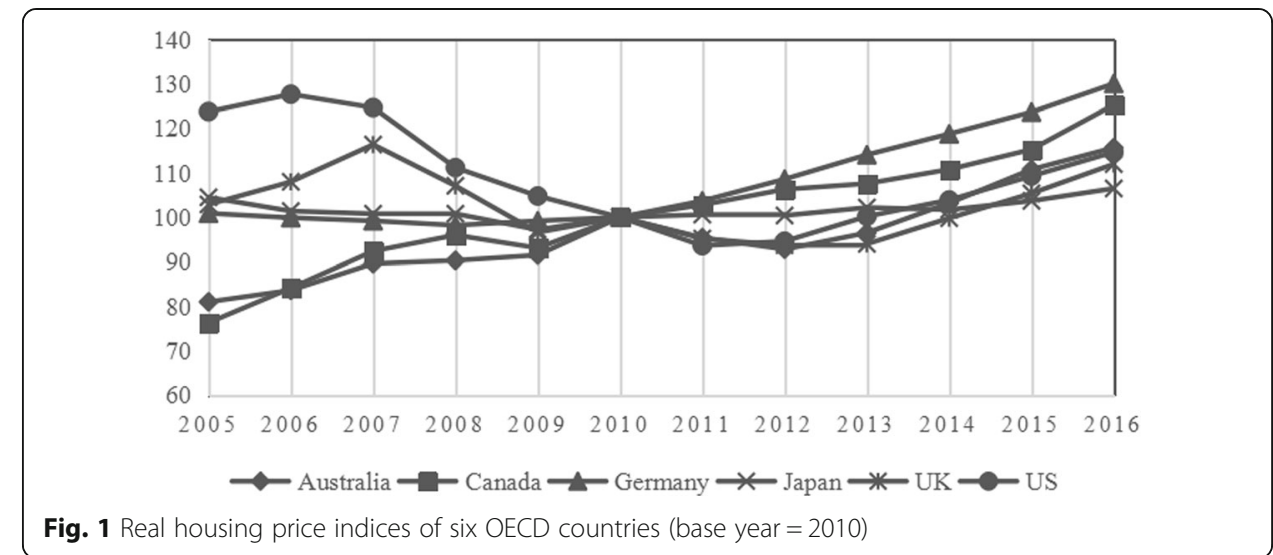

to its housing market. To disentangle this phenomenon, this paper attempts to shed light on international housing price co-movement from country responses.

The extant literature on housing markets primarily focuses on geographic, economic and capital channels to interpret international housing market co-movements, but does not take culture into account (e.g., Holly et al. 2011; Hirata et al. 2012; Cesa-Bianchi 2013; Eickmeier et al. 2014; Milcheva and Zhu 2016). In fact, cultural similarities between country pairs are highly associated with corresponding house price correlations (see Fig. 2). Moreover, there is a trend in finance research that interprets stockholders' preference and behavior by virtue of cultural similarities (Grinblatt and Keloharju 2001; Brown and Mitchell 2008; Catao and Timmermann 2010; Beine et al. 2010; Kumar et al. 2011; Bekaert et al. 2011; Eun et al. 2015; Hilary and Hui 2009; Ang et al. 2015; Sarkissian and Schill 2004; Chakrabarti et al. 2009). Hence, it is possible that culture similarities may also link international housing market co-movements in a manner similar to capital market interdependence. To the best of our knowledge, this paper is the first to explore the role of culture similarities in international housing price co-movements.

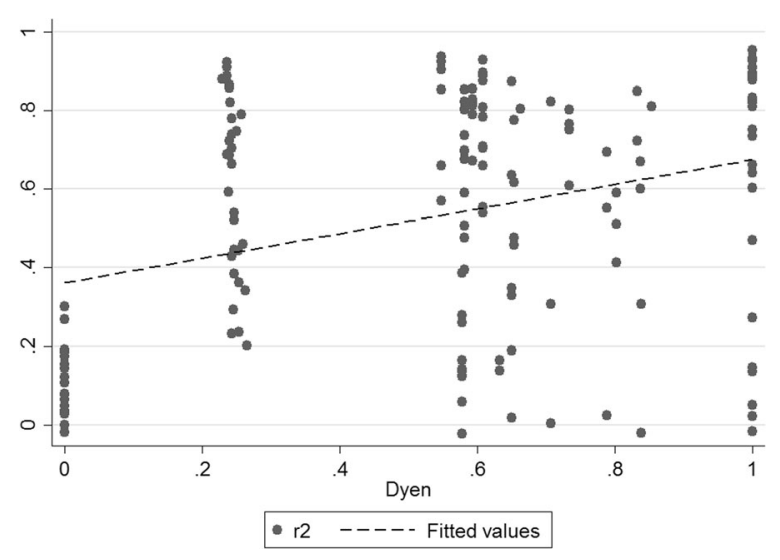

Fig. 2 Cultural similarity index (Dyen Index) and house price correlation $\left(R^{2}\right)$ 


\section{Literature review}

Previous research examines the existence, metrics and time-varying properties of housing market linkages (Clapp et al. 1995; Pollakowski and Ray 1997; Dees et al. 2007; Vansteenkiste and Hiebert 2011; Chudik and Fratzscher 2011; Chen et al. 2011; Cotter et al. 2011; Holly et al. 2011; Hoesli and Reka 2013; Cesa-Bianchi 2013; Brady 2014; Engsted and Pedersen 2014; Gupta et al. 2014; Kallberg et al. 2014; Milcheva and Zhu 2016; Wu and Deng 2015; Cohen et al. 2016; Teye and Ahelegbey 2017). To name a few, using the town-level databases of the state of Connecticut and the City of San Francisco, Clapp et al. (1995) found that housing price linkage is more pronounced in neighboring towns. Brady (2014) adopted a spatial autoregressive model and impulse response function to estimate the speed and duration of spatial house price diffusion across the US from 1975 to 2011. Employing a repeated home sales price index of 384 Metropolitan Statistical Areas (MSAs) conducted by the Federal Housing Finance Agency, Cotter et al. (2011) used $R$-squared to measure housing market integration and found that $R$-squared increases over time. Vansteenkiste and Hiebert (2011) utilized the quarterly data sets of housing price indices in 10 European countries to find that house price spillovers are limited but vary across countries. Milunovich and Trück (2013) employed real estate investment trusts databases in North America, Europe and AsiaPacific and identified an increase in the frequency of contagion during the 2007-2009 global financial crisis. Using databases of housing price indices in the US, the UK and Australia from 1990 to 2010, Hoesli and Reka (2013) analyzed tail dependence as characterizing cross-market linkages and identified an asymmetric linkage across markets. Cohen et al. (2016) utilized panel data from 375 MSAs across the US from 1975 to 2007, and found that there is a notable spatial diffusion pattern in inter-MSA house prices in addition to an MSA's own lagged-price changes. Employing the quarterly house price indices between 1995Q1 and 2016Q1 for owner-occupied dwellings in the Netherlands, Teye and Ahelegbey (2017) adopted Bayesian graphical vector autoregression (BG-VAR) to illuminate house price diffusion patterns in distinct sub-periods from different provincial housing sub-markets in the Netherlands.

Other literature focuses on the linkages between housing market co-movements (Harding et al. 2009; Holly et al. 2011; Hirata et al. 2012; Cesa-Bianchi 2013; Eickmeier et al. 2014; Paltalidis et al. 2015; Milcheva and Zhu 2016; Jara and Romero, 2016; Ballester et al. 2016; Landier et al. 2017). The first strand of literature explains house price co-movement through geography and trade channels. For instance, using quarterly real house price databases from London and eleven other regions in the UK from 1973Q4 to 2008Q2, Holly et al. (2011) found that house price shocks in London's dominant region propagate spatially to the other eleven regions and the diffusion effects decay with geographic distance from London. Vansteenkiste and Hiebert (2011) applied bilateral trade volume and geographic distance to represent linkages and found both are significant determinants of housing market linkage. The second strand of literature addresses housing market linkages in terms of debt and banking. Harding et al. (2009) used a private mortgage database and generated repeated sales pairs from the GSE loan database for the corresponding 140 zip codes over the period 1989-2007, and found the presence of distressed properties results in a roughly $1 \%$ lower sales price for nearby non-distressed properties, whose contagion effect diminishes rapidly with far distance to the distressed properties. Paltalidis et al. (2015) investigated quarterly data 
for 16 Eurozone countries from 2005Q1 to 2013Q4 to demonstrate that sovereign credit risk is the primary source of banking contagion. Utilizing quarterly data sets of the house price indices in 17 OECD countries during the period from 1990 to 2012, Milcheva and Zhu (2016) found that banking integration and the maturity of local mortgage markets significantly affected the linkage of housing returns in addition to trade, FDI, market openness, geographic proximity, and portfolio investment. Similarly, using a balanced panel of all US state pairs from 1976 to 2000, Landier et al. (2017) documented that house price growth correlation is strongly driven by banking integration. Employing a panel database of quarterly real housing prices for 22 advanced and 31 emerging economies from 2000Q1 to 2014Q4, Jara and Romero (2016) also found that banking integration positively and significantly affects the synchronicity of housing prices. The third strand of literature analyzes housing price synchronization from liquidity or capital perspective (Longstaff 2010; Hoesli and Reka 2015; Cesa-Bianchi et al. 2015; Eickmeier and Ng 2015; Liao et al. 2015; Hau and Lai 2017). Employing daily data from the ABX Indices of collateralised-debt obligations (CDOs) from January 19, 2006 to December 31, 2008, Longstaff (2010) found that the return volatility of subprime CDOs is able to predict the return volatility of stocks and bonds 3 weeks before, which is propagated via liquidity and risk-premium channels rather than by correlated-information channels. Utilizing the U.S. REIT market data during the period 1999-2011, Hoesli and Reka (2015) documented that liquidity can help explain contagion between real estate and financial markets, while there is no evidence of the impact of portfolio rebalancing and correlated information channels on contagion. Using a quarterly house price data set for 33 emerging markets and 24 advanced economies from the early 2000s to 2012, Cesa-Bianchi et al. (2015) found that house prices in emerging economies are more closely connected with capital flows than in advanced economies. Controlling for the transmission channels of bilateral trade, portfolio investment, foreign investment and banking exposures, Eickmeier and $\mathrm{Ng}$ (2015) found that both bilateral trade and inward FDI or outward banking exposure fit the data better than only bilateral trade in interpreting external credit supply shocks. Based on the return shortfall of mutual funds between July 1, 2007 and June 30, 2008, Hau and Lai (2017) provided evidence that funding liquidity plays an important role in the transmission of the crisis from financial stocks to non-financial stocks.

To summarize, this paper seeks to fill the gaps in the literature by combining culture similarities and the responses of a country to another country that is the source of housing price contagion. Employing databases on cultural similarities, housing market conditions and housing security systems in 18 OECD countries from 1970 to 2016, this paper applies a spatial autoregressive (SAR) model to examine whether culture affects international housing price linkage via information dissemination efficiency and investment conduct consistency. Meanwhile, housing supply elasticity and housing security systems can help mitigate international house price contagion. The remainder of this paper proceeds as follows. Hypotheses section puts forward empirical hypotheses regarding the culture and responses of countries to housing price contagion. Data, Methodology and Descriptive Analysis section describes the data, methodology and statistical analysis. Results section employs a spatial econometric model to test the hypotheses. Conclusions and Policy Implications section presents conclusions and policy implications. 


\section{Hypotheses}

As discussed above, culture links various markets by virtue of information dissemination efficiency and conduct conformity (Case and Shiller 1989; Oikarinen 2004; Hong and Stein 2007; Ferreira and Gyourko 2012; Wu and Deng 2015). Culture affects the timing and efficiency of information dissemination in different markets through transaction costs, information asymmetry and unfamiliarity effects (Lucey and Zhang 2010; Wu and Deng 2015). In other words, cultural affinity facilitates market linkage. In addition, culture is an important determinant of people's conducts and thoughts (Shiller 1999). That is, people with similar cultural backgrounds are more likely to react in the same manner to the same shocks (Grinblatt and Keloharju 2001; Lucey and Zhang 2010; Lievenbrück and Schmid 2014; Eun et al. 2015). Likewise, taking the severe information asymmetry of a direct real estate market into account, culture can also link housing prices in different direct housing markets by means of information dissemination efficiency and conduct conformity. Hence, we hypothesize:

H1: Cultural similarities increase housing market linkage.

H2: The more efficient the information dissemination is, the greater influences the cultural similarity has on housing market linkage.

H3: The more consistent the investment conduct is, the greater influences the cultural similarity has on housing market linkage.

In essence, housing price linkage not only relies on the effectiveness of linkage channels, but also hinges on the responses of countries to external shocks. Housing market conditions affect the responses to external shocks. In other words, the paces of response of housing supply and housing demand to external shocks determine housing price linkage. Housing supply elasticity is the crucial determinant of house prices and their volatility (Malpezzi and Maclennan 2001; Harter-Dreiman 2004; Saiz 2010; Andrews et al. 2011; Paciorek 2013). That is, the greater the housing supply elasticity is, the less volatile housing prices are. Hence, we hypothesize:

H4: Greater housing supply elasticity of a country can mitigate the effect of cultural similarities on housing price linkage.

In addition to housing market conditions, government participation in the housing market also affects shock responsiveness. Government participation includes social housing policies, to benefit low-income and first-time homebuyers, tax policies and housing finance polices. As mentioned above, Yu (2010) found that liberal housing market patterns represented by Australia and the UK are market-dominated and involve less government intervention, and are more subject to housing price shocks. By contrast, countries such as Canada combine the market mechanism with public intervention and are more capable of resisting external shocks. In addition, Carstensen et al. (2009) also demonstrated that more flexible housing mortgage policies will result in less pronounced influences to monetary shocks. Hence, we hypothesize:

H5: Greater government participation in a country can mitigate the effect of cultural similarities on housing price linkage. 


\section{Data, methodology and descriptive analysis \\ Data}

We used data from 18 OECD countries from 1970 to 2016. The 18 OECD countries comprise of Australia, Belgium, Canada, Denmark, Finland, France, Germany, Ireland, Italy, Japan, the Netherlands, New Zealand, Norway, Spain, Sweden, Switzerland, the UK and the US. Nevertheless, our samples are representative. The total GDP and trade volume of the 18 OECD countries account for $85 \%$ and $82 \%$ of all OECD countries during the sample period, respectively. Additionally, the 18 OECD countries are widely distributed in Asia, North America, Oceania and Europe.

The real housing price indices are computed based on the OECD Analytical House Prices Indicators database. The linguistic proximity indices are collected from Dyen et al. (1992) and Adsera and Pytlikova (2015), respectively. The religious similarity indices are obtained from the World Factbook (WF). The media coverage raw data is from ABYZ new links-Newspaper and News Media Guide. Geographic distance is computed from the CEP II database. Bilateral trade data is from the OECD International Trade database. The raw data for the real estate FDI restrictiveness index is from the OECD Globalization database. The data of the days to obtain a building permit is gathered from World Bank Doing Business (2009), and estimated housing supply elasticity is sourced from Caldera and Johansson (2013). The government participation indices are issued by the IMF. Moreover, the data of control variables including GDP per capita, long-term interest rates and population density are available from the OECD National Accounts database.

\section{Key variables}

Housing prices

For comparison and controlling for time-fixed effects, this paper applies the real housing price indices of the 18 OECD countries with the base year $2010=100$. In addition, we take the logarithm of real housing price indices to smooth steadiness.

\section{Cultural similarity indices}

A cultural distance index is normally used to measure cultural similarities between countries (Weber et al. 1996), albeit Hofstede's cultural dimensions are also widely employed to represent the culture and value systems of a country (Hofstede 1994; Stulz and Williamson 2003; Chui et al. 2010; Lievenbrück and Schmid 2014; Eun et al. 2015; Ahern et al. 2015; Boubakri and Saffar 2016; Chui et al. 2016). As language and religion can serve as proxies for culture (La Porta et al. 1999; Diaz 2000; Lucey and Zhang 2010; Kumar et al. 2011; Fischer 2012; Adhikari and Agrawal 2016), this paper employs linguistic and religious similarities to gauge cultural distance and capture cultural similarities. Typically, linguistic proximity is perceived as a proxy for information dissemination efficiency (Grinblatt and Keloharju 2001; Lane and Milesi-Ferretti 2008; Catao and Timmermann 2010; Wälti 2011; Beine et al. 2010; Bekaert et al. 2011), while religious similarity represents investment conduct consistency (La Porta et al. 1999; Guiso et al. 2003; Kumar et al. 2011). Accordingly, this paper employs linguistic and religious similarities to test the mechanism of information dissemination efficiency and conduct consistency. $^{2}$

(1) linguistic proximity index 
First, this paper adopts the linguistic proximity index proposed by Adsera and Pytlikova (2015), labeled as API. API is defined as the language-levels of linguistic family tree both the affected and source-of-contagion countries share. API ranges from 0 to 1 , which is weighted by each language-level of the linguistic family tree. In addition to API, we apply the Dyen index (Dyen et al. 1992) for a robustness check. The Dyen index is continuous from 0 and 1 , which is built on the similarities of phonetics and words in two languages. It is noteworthy that we take the maximum proximity value of the official languages of country pairs to construct a linguistic proximity index, which is superior to a linguistic proximity dummy variable if country pairs with more than one official language share the same official languages.

(2) religious similarity index

We evaluate religious similarity between country pairs in terms of the WF. We borrow the KS law (Kogut and Singh 1988) to compute the religious similarity index as follows:

$$
W F_{a b}^{1}=\frac{1}{K S_{a b}}=\frac{1}{\sum_{i=1}^{n} \frac{\left[\left(P_{a i}-P_{b i}\right)^{2} / V_{i}\right]}{n}},
$$

where $K S_{a b}$ denotes religious distance between countries $a$ and $b, P_{a i}$ and $P_{b i}$ stand for population fractions of the $i_{t h}$ religion in countries $a$ and $b$, respectively, $\mathrm{n}$ is the least common multiple of overall religion kinds of country pairs, $V_{i}$ is the weight variance of the $i_{t h}$ religion in all countries. Hence, we take the reciprocal of $K S_{a b}$ to derive a religious similarity index of $W F_{a b}^{1} \cdot{ }^{3}$ For the sake of robustness checks, we construct another religious similarity index of $W F_{a b}^{2}$, which is the sum of the products of religion proportions in country pairs. Namely,

$$
W F_{a b}^{2}=\sum_{i=1}^{n} P_{a i}{ }^{*} P_{b i}
$$

\section{Mechanism}

\section{(1) information dissemination efficiency}

As discussed above, since cultural similarities affect the pace and accuracy of information dissemination, they can decide information dissemination efficiency via linguist proximity in some sense. Busse and Green (2002) found that media coverage can stimulate transactions between buyers and sellers and can be reflected in stock prices. Yuan (2015) noted that media coverage provokes investors to trade more frequently. Kurlat and Stroebel (2015) argued that information is more quickly and accurately reflected in stock prices if information asymmetry between buyers and sellers is lower. Thus, we take the frequency of foreign media coverage in the official language of a country to gauge information dissemination efficiency. Namely,

$$
\operatorname{MedC}_{a b}=\sum_{i=1}^{n} I\left(\text { Langu_media }_{a, i}=\operatorname{Langu}_{b}\right),
$$

where $a, b$ denote country where the shock originated and country affected by contagion, respectively. $M e d C_{a b}$ denotes the frequency of media coverage in the official 
language of country $b$ in country $a$. Langu_media $a$ is the official language of the $i_{\text {th }}$ media in country $a$, Langu $_{b}$ is the official language of countries $b . I(\cdot)$ is a characteristic function which equals to one in the event that the equation in parenthesis holds. As overall media coverage might vary markedly across countries, Media $_{a b}$ is standardized for comparison as follows:

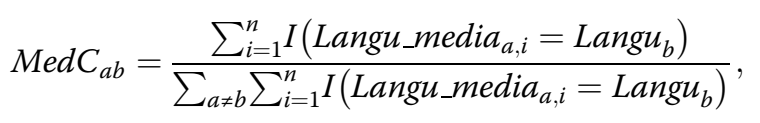

where $\sum N(\operatorname{Langu}(a)=\operatorname{Langu}(b))$ denotes the overall foreign media coverage in the official laknguage of country $b$.

(2) conduct consistency

In theory, asset price is a comprehensive reflection of investors' behavior patterns and attitudes. As a consequence, investors in a country with a diversified culture respond to external shocks differently, which maps asset prices in diverse directions and weakens asset price linkages. Conversely, investors in a country with a more unified culture respond identically, which engenders stronger asset price linkages. Thus, we introduce concentration of religion to gauge investment conduct conformity. The religious Herfindal index of religion concentration can be written as:

$$
H I_{b}=\sum \rho_{b, i}{ }^{2},
$$

where $b$ denotes a home country, $\rho_{\mathrm{b}, \mathrm{i}}$ stands for the fraction of the $i_{\text {th }}$ religion in country $b$. Apparently, investment conduct conformity increases with the religious Herfindal index.

\section{Other transmission channels}

As mentioned above, geographic, economic and capital channels matter for international market linkages. Hence, this paper controls for the effects of the geographic, economic and capital channels on international housing price linkage.

\section{(1) geographic channel}

Following Asgharian et al. (2013), we develop the geographic proximity index as follows:

$$
G e o_{i, j}=\frac{\max _{i, j} \text { Dist }_{i, j}-\text { Dist }_{i, j}}{\max _{i, j} \text { Dist }_{i, j}-\min _{i, j} \text { Dist }_{i, j}},
$$

where Dist $_{i, j}$ is the geographic distance between the capital cities of country pairs, $G e o_{i,}$ $j$ takes the value of 1 if country $j$ is the nearest to country $i$, and equals to 0 if the farthest. It is noteworthy that for country pairs whose capital cities are rather far but share the same borders, we let $G e o_{i, j}=1$, otherwise 0 .

(2) trade channel

Trade is normally and widely considered to be a catalyzer of economic co-movements across countries (Wälti 2011; Asgharian et al. 2013; Milcheva and Zhu 2016). 
Similarly, trade also affects international housing price synchronization via common economic linkage. Following Asgharian et al. (2013) and Milcheva and Zhu (2016), we construct the trade share as follows:

$$
\operatorname{Tr}_{i, j, t}=\frac{\text { export }_{i, j, t}+\text { import }_{i, j, t}}{\sum_{n=1}^{17} \operatorname{export}_{i, n, t}+\sum_{n=1}^{17} \text { import }_{i, n, t}},
$$

where export $_{i, j, t}$ and import $_{i, j, t}$ are pecuniary export and import volumes from country $i$ to country $j$ in year $t$, respectively, while $\sum_{n=1}^{17} \operatorname{export}_{i, n, t}$ and $\sum_{n=1}^{17}$ import $_{i, n, t}$ are overall pecuniary export and import volumes from country $i$ to the rest of countries, respectively.

(3) capital channel

Following Milcheva and Zhu (2016), the capital channel of country pairs can be built on the minimum openness index of real estate FDI as follows:

$$
F D I_{i, j, t}^{o p e n}=\operatorname{Min}\left(1-R I_{i}, 1-R I_{j}\right)
$$

where $R I$ denotes a real estate FDI restrictiveness index.

\section{Country responses}

(1) housing supply elasticity

We first employ the estimated housing supply elasticities of OECD countries proposed by Caldera and Johansson (2013) to serve as the elasticities of housing supply. Caldera and Johansson) documented that housing supply elasticity is not only determined by geographical and urban characteristics, but also determined by land use and planning regulations. In addition, as Malpezzi (1996) and Gyourko (2009) believe, the days to obtain a building permit and residential buildings permits issued are ideal proxies for housing supply elasticity. Thus, for circumventing the endogeneity problem, we take the reciprocal of the days to obtain a building permit to proxy for housing supply elasticity SupE.

\section{(2) government participation}

As discussed before, the housing security system of a country (e.g., public intervention) determines the extent of the response of domestic housing markets to external shocks (Yu 2010). Hence, we apply the index of government participation (GovP) in the housing market issued by the International Monetary Fund (2011) as a proxy for a housing social security system. GovP measures the degree of government participation in the housing market, which is constructed using data on housing subsidies, tax incentives, and housing finance guarantees. 


\section{Econometric setup}

Spatial econometric models are widely applied to explore spatial linkages (Li et al. 2008; Monkkonen et al. 2012; Hu et al. 2013; Brady 2014; Nanda and Yeh 2014; Thanos et al. 2016). In terms of spatial dependency, spatial econometric models are normally categorized into spatial autoregressive models (SAR) and spatial errors models (SEM). To investigate the spatial linkage of international housing prices, this paper adopts the SAR model. As the spatial weight matrix is the pivot to the SAR model, this paper uses cultural similarity as the spatial weight matrix. Moreover, to control for the effects of the other spatial linkages on international housing price co-movement, we adopt an SAR model with two spatial weight matrices proposed by Asgharian et al. $(2013)^{4}$ :

$$
R H P_{t}=\rho_{1} W_{1 t} R H P_{t}+\rho_{2} W_{2 t} R H P_{t}+X_{t} \beta+D \alpha+\varepsilon_{t},
$$

where $R H P_{t}$ stands for an $N^{*} 1$ vector of real house prices. $N$ denotes the number of countries. $W_{1}$ is a standardized spatial weight matrix of cultural similarity, with zero diagonal elements to eliminate the influence of domestic housing prices and the offdiagonal elements to represent cultural similarity. $W_{2}$ is the other spatial matrices including trade, geographic and capital channels. $W_{1 t} R H P_{t}$ multiplies the spatial weight matrices of culture similarity with the real housing price matrix and captures the weighted real house prices of the other $N-1$ countries through culture, while $W_{2 t} R H P_{t}$ is the spatially weighted house price via other linkage channels. $\rho_{1}$ is the spatial autoregressive parameters of cultural similarity. $X_{t}$ is an $N^{*} K$ matrix that controls for the country-specific variables including population density $(P D)$, GDP per capita (GDPpc) and long-term interest rate $(L I R), \beta$ denotes a coefficient vector of domestic variants, $D$ stands for country-specific fixed effects, and $\varepsilon_{t}$ is the error term. Maximum likelihood estimation is used to yield consistent parameter estimates.

In addition, to examine the interaction of cultural similarities with the mechanism and the responses of a country, following Milcheva and Zhu (2016), we can expand the above baseline SAR model into following SAR models:

$$
\begin{aligned}
& R H P_{t}=\left(\rho_{1}+\rho_{1}^{*} \cdot \operatorname{MedC}\right) W_{1 t} R H P_{t}+\rho_{2} W_{2 t} R H P_{t}+X_{t} \beta+D \alpha+\mu_{t} \\
& R H P_{t}=\left(\rho_{1}+\rho_{1}^{*} \cdot H I\right) W_{1 t} R H P_{t}+\rho_{2} W_{2 t} R H P_{t}+X_{t} \beta+D \alpha+\gamma_{t} \\
& R H P_{t}=\left(\rho_{1}+\rho_{1}^{*} \cdot \operatorname{Sup} E\right) W_{1 t} R H P_{t}+\rho_{2} W_{2 t} R H P_{t}+X_{t} \beta+D \alpha+\delta_{t} \\
& R H P_{t}=\left(\rho_{1}+\rho_{1}^{*} \cdot G o v P\right) W_{1 t} R H P_{t}+\rho_{2} W_{2 t} R H P_{t}+X_{t} \beta+D \alpha+\vartheta_{t}
\end{aligned}
$$

where $\rho_{1}^{*}$ is the coefficient of the interaction term.

Finally, to detect whether the effects of cultural similarities are significant and valid, the SAR model first follows Milcheva and Zhu (2016) and simultaneously incorporates only one other linkage channel into culture each time to resolve multicollinearity problems. Second, theoretically, the current and future domestic housing price movement normally does not affect the lagged spatial housing price linkage; therefore we apply the lagged spatial weighted real housing price matrix to resolve endogeneity issues. On the other hand, if we introduce $\mathrm{AR}(1)$ to control for the inter-temporal effects, there exist severe multicollinearity problems between the lagged housing price and the lagged spatial weight matrices. Hence, it allows us to exclude inter-temporal effects in the SAR model. Third, as the structural changes of some influential factors might vary over 
time, we employ Chow-tests to test the time-varying structural changes prior to and after the subprime crisis of 2008. The results show that some factors such as the trade weight matrix, geographic weight matrix, population density and long-term interest rate underwent significant structural changes after the subprime crisis of 2008, whilst the culture and FDI weight matrices did not show significant time structural change. As this paper focuses on culture similarities, we do not consider the time structural change of other linkage channels. ${ }^{5}$ Lastly, to address fake regression, we employ unit root tests and co-integration tests to decide the specification of the SAR model. The results corroborate that we can apply the level equation of the SAR model. ${ }^{6}$

\section{Descriptive analysis}

Table 1 shows that the housing prices in Australia (AUS) are highly correlated with the other 17 countries, in which there are 6 countries with the $R$-squared above 0.9. Thus, house prices in Australia are susceptible to external shocks. The countries with a smaller $R$-squared encompass Japan (JPN), Switzerland (CHE) and Germany (GER), which indicate that they are less prone to external shocks. The $R$-squared of New Zealand (NZL), United Kingdom (UK), France (FRA), Canada (CAN) and the United States (US) varies from 0.2 to 0.95 .

Figure 3 depicts the relationship between housing price linkage and the Dyen index of cultural similarity. As shown in Fig. 3, the three housing price linkage indices of beta, correlation, and $R$-squared are positively relevant to cultural similarity.

Table 2 shows that there are 131 US media outlets reporting in the official languages of Australia, Ireland, New Zealand and UK, whilst 0 US media outlets reporting in the official languages of Denmark, Finland, Germany, Italy, Japan, Netherlands, Norway, and Switzerland. Moreover, Denmark, Japan, and Norway can disseminate information

Table 1 Housing price correlation matrix across 18 OECD countries

\begin{tabular}{|c|c|c|c|c|c|c|c|c|c|c|c|c|c|c|c|c|c|c|}
\hline$\overline{R^{2}}$ & AUS & BEL & CAN & DEN & FIN & FRA & GER & IRL & ITA & JPN & NLD & NZL & NOR & ESP & SWE & $\mathrm{CHE}$ & UK & US \\
\hline AUS & 1.00 & & & & & & & & & & & & & & & & & \\
\hline BEL & 0.93 & 1.00 & & & & & & & & & & & & & & & & \\
\hline CAN & 0.93 & 0.89 & 1.00 & & & & & & & & & & & & & & & \\
\hline DEN & 0.79 & 0.82 & 0.67 & 1.00 & & & & & & & & & & & & & & \\
\hline FIN & 0.75 & 0.61 & 0.72 & 0.59 & 1.00 & & & & & & & & & & & & & \\
\hline FRA & 0.93 & 0.93 & 0.91 & 0.82 & 0.73 & 1.00 & & & & & & & & & & & & \\
\hline GER & 0.33 & 0.29 & 0.22 & 0.50 & 0.49 & 0.39 & 1.00 & & & & & & & & & & & \\
\hline IRL & 0.72 & 0.75 & 0.53 & 0.85 & 0.53 & 0.72 & 0.52 & 1.00 & & & & & & & & & & \\
\hline ITA & 0.51 & 0.56 & 0.49 & 0.38 & 0.39 & 0.63 & 0.25 & 0.56 & 1.00 & & & & & & & & & \\
\hline JPN & 0.12 & 0.17 & 0.07 & 0.26 & 0.01 & 0.15 & 0.08 & 0.12 & 0.00 & 1.00 & & & & & & & & \\
\hline NLD & 0.73 & 0.83 & 0.56 & 0.81 & 0.46 & 0.70 & 0.43 & 0.90 & 0.48 & 0.19 & 1.00 & & & & & & & \\
\hline NZL & 0.95 & 0.90 & 0.90 & 0.83 & 0.70 & 0.90 & 0.32 & 0.70 & 0.45 & 0.14 & 0.68 & 1.00 & & & & & & \\
\hline NOR & 0.93 & 0.87 & 0.90 & 0.81 & 0.73 & 0.89 & 0.32 & 0.62 & 0.34 & 0.18 & 0.65 & 0.92 & 1.00 & & & & & \\
\hline ESP & 0.77 & 0.79 & 0.66 & 0.76 & 0.67 & 0.82 & 0.56 & 0.87 & 0.71 & 0.04 & 0.79 & 0.73 & 0.62 & 1.00 & & & & \\
\hline SWE & 0.81 & 0.79 & 0.83 & 0.68 & 0.57 & 0.81 & 0.17 & 0.46 & 0.31 & 0.31 & 0.51 & 0.79 & 0.84 & 0.48 & 1.00 & & & \\
\hline $\mathrm{CHE}$ & 0.13 & 0.04 & 0.23 & 0.01 & 0.34 & 0.12 & 0.00 & 0.00 & 0.05 & 0.13 & 0.01 & 0.10 & 0.13 & 0.04 & 0.14 & 1.00 & & \\
\hline UK & 0.94 & 0.87 & 0.83 & 0.83 & 0.81 & 0.91 & 0.45 & 0.84 & 0.56 & 0.07 & 0.77 & 0.90 & 0.86 & 0.87 & 0.69 & 0.13 & 1.00 & \\
\hline US & 0.75 & 0.75 & 0.60 & 0.81 & 0.59 & 0.75 & 0.43 & 0.93 & 0.59 & 0.06 & 0.81 & 0.74 & 0.66 & 0.85 & 0.47 & 0.02 & 0.89 & 1.00 \\
\hline
\end{tabular}




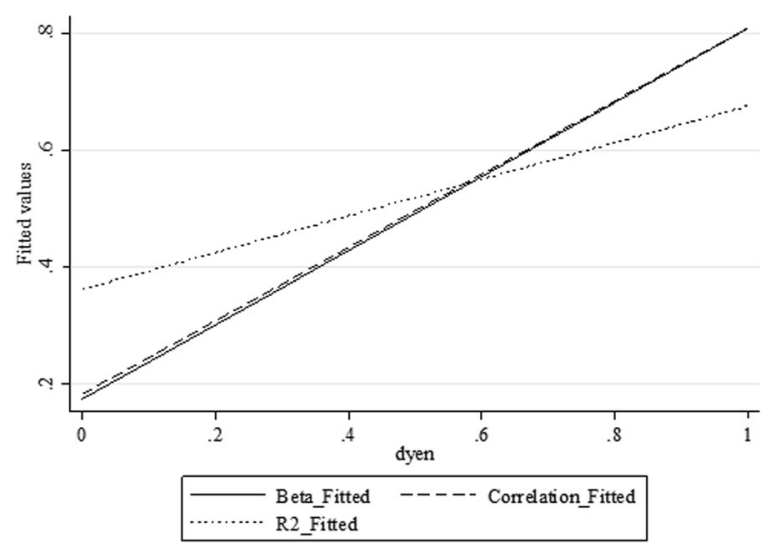

Fig. 3 Cultural similarities and housing price linkage

via media world-widely, but they cannot acquire information from other countries in their own official languages. It implies lower information dissemination efficiency and higher information asymmetry across these countries.

Table 3 shows that the religious concentrations of Spain and Sweden are highest with Herfindal indices of 0.884 and 0.757 respectively in that their majority religions account for 94 and $87 \%$ respectively. Thereby, it can be postulated that the investment behavior consistency is higher in Spain and Sweden. New Zealand has the lowest religious concentration with a Herfindal index of 0.014 in the sense that its largest religious concentration is Catholicism which barely accounts for $11.6 \%$. Likewise, investment behavior consistency in New Zealand is inferred to be lower.

Table 4 shows that the US has the greatest housing supply elasticity at 2.014, whereas the Netherlands has the lowest housing supply elasticity at 0.186 , which suggests that the housing supply in the US is more resilient than that in the Netherlands.

Table 5 demonstrates that the index of government participation in housing markets in the US is the highest, accounting for $56 \%$, followed by the Netherlands and Canada accounting for 50 and $44 \%$, respectively. The lowest index of government participation in the housing market is the UK, at only $13 \%$. Thereby, government participation in the housing market varies vastly across OECD countries.

\section{Results}

\section{Results of hypothesis 1}

Table 6 presents the results of four cultural similarity indices shown as the metrics of spatial weight matrices. It is evident that the spatial parameters are significant across culture similarities, in that housing price fluctuations in other countries exert positive and robust impacts on domestic housing prices via cultural channels. Accordingly, the results support Hypothesis 1 . The other spatial matrices of geographic, trade and capital channels do not affect the significance of the cultural channel, and only trade and geographic weight matrices significantly affect international housing price co-movements, whereas the FDI weight matrix does not significantly affect international housing market linkages. The results seem to be inconsistent with the extant literature, which primarily considers only one spatial weight matrix. The signs of the GDP per capita, population density and long-term interest rate conform to our theoretical expectations. 
Table 2 Frequency of foreign media coverage in domestic official languages across 18 OECD countries

\begin{tabular}{lllllllllllllllllll}
\hline & AUS & BEL & CAN & DEN & FIN & FRA & GER & IRL & ITA & JPN & NLD & NZL & NOR & ESP & SWE & CHE & UK & US \\
\hline AUS & 0 & 2 & 35 & 0 & 0 & 2 & 0 & 33 & 0 & 0 & 0 & 33 & 0 & 0 & 0 & 2 & 33 & 33 \\
BEL & 7 & 0 & 14 & 0 & 0 & 7 & 1 & 7 & 0 & 0 & 14 & 7 & 0 & 0 & 0 & 8 & 7 & 7 \\
CAN & 41 & 11 & 0 & 0 & 0 & 11 & 0 & 41 & 0 & 0 & 0 & 41 & 0 & 1 & 0 & 11 & 41 & 41 \\
DEN & 8 & 0 & 8 & 0 & 0 & 0 & 0 & 8 & 0 & 0 & 0 & 8 & 0 & 0 & 0 & 0 & 8 & 8 \\
FIN & 10 & 0 & 10 & 0 & 0 & 0 & 0 & 10 & 0 & 0 & 0 & 10 & 0 & 0 & 1 & 0 & 10 & 10 \\
FRA & 10 & 17 & 27 & 0 & 0 & 0 & 0 & 10 & 0 & 0 & 0 & 10 & 0 & 0 & 0 & 17 & 10 & 10 \\
GER & 9 & 26 & 9 & 0 & 0 & 0 & 0 & 9 & 0 & 0 & 0 & 9 & 0 & 0 & 0 & 26 & 9 & 9 \\
IRL & 12 & 1 & 13 & 0 & 0 & 1 & 0 & 0 & 0 & 0 & 0 & 12 & 0 & 0 & 0 & 1 & 12 & 12 \\
ITA & 10 & 1 & 11 & 0 & 0 & 1 & 0 & 10 & 0 & 0 & 0 & 10 & 0 & 0 & 0 & 14 & 10 & 10 \\
JPN & 13 & 1 & 14 & 0 & 0 & 1 & 0 & 13 & 0 & 0 & 0 & 13 & 0 & 0 & 0 & 1 & 13 & 13 \\
NLD & 18 & 22 & 19 & 0 & 0 & 1 & 0 & 18 & 0 & 0 & 0 & 18 & 0 & 1 & 0 & 1 & 18 & 18 \\
NZL & 22 & 0 & 22 & 0 & 0 & 0 & 0 & 22 & 0 & 0 & 0 & 0 & 0 & 0 & 0 & 0 & 22 & 22 \\
NOR & 10 & 0 & 10 & 0 & 0 & 0 & 0 & 10 & 0 & 0 & 0 & 10 & 0 & 0 & 0 & 0 & 10 & 10 \\
ESP & 10 & 1 & 11 & 0 & 0 & 1 & 0 & 10 & 0 & 0 & 0 & 10 & 0 & 0 & 0 & 1 & 10 & 10 \\
SWE & 8 & 2 & 9 & 0 & 16 & 1 & 1 & 8 & 0 & 0 & 0 & 8 & 0 & 0 & 0 & 2 & 8 & 8 \\
CHE & 8 & 9 & 12 & 0 & 0 & 4 & 5 & 8 & 2 & 0 & 0 & 8 & 0 & 0 & 0 & 0 & 8 & 8 \\
UK & 34 & 1 & 35 & 0 & 0 & 1 & 0 & 34 & 0 & 0 & 0 & 34 & 0 & 1 & 0 & 1 & 0 & 34 \\
US & 131 & 1 & 132 & 0 & 0 & 1 & 0 & 131 & 0 & 0 & 0 & 131 & 0 & 5 & 0 & 1 & 131 & 0 \\
\hline
\end{tabular}

Table 3 Religious concentration across 18 OECD countries

\begin{tabular}{lllllll}
\hline Country & Majority religion & Protestant & Catholic & Muslim & Buddhist & Herfindal Index \\
\hline AUS & Protestant & $30.10 \%$ & $25.30 \%$ & $2.50 \%$ & $2.80 \%$ & 0.156 \\
BEL & Catholic & $0 \%$ & $75 \%$ & $0 \%$ & $0 \%$ & 0.563 \\
CAN & Catholic & $20.30 \%$ & $40.60 \%$ & $3.20 \%$ & $1.10 \%$ & 0.207 \\
DEN & Protestant & $80 \%$ & $0 \%$ & $4 \%$ & $0 \%$ & 0.642 \\
FIN & Protestant & $78.40 \%$ & $0 \%$ & $0 \%$ & $0 \%$ & 0.615 \\
FRA & Catholic & $0 \%$ & $66 \%$ & $9 \%$ & $0.75 \%$ & 0.444 \\
GER & Protestant & $34 \%$ & $34 \%$ & $3.70 \%$ & $0 \%$ & 0.233 \\
IRL & Catholic & $0 \%$ & $84.70 \%$ & $1.10 \%$ & $0 \%$ & 0.718 \\
ITA & Catholic & $0 \%$ & $80 \%$ & $2.50 \%$ & $0 \%$ & 0.641 \\
JPN & Buddhist & $0 \%$ & $1.50 \%$ & $0 \%$ & $66.80 \%$ & 0.446 \\
NLD & Catholic & $19 \%$ & $28 \%$ & $5 \%$ & $0 \%$ & 0.117 \\
NZL & Catholic & $0 \%$ & $11.60 \%$ & $0 \%$ & $1.40 \%$ & 0.014 \\
NOR & Protestant & $82.10 \%$ & $1.80 \%$ & $2.30 \%$ & $0 \%$ & 0.675 \\
ESP & Catholic & $0 \%$ & $94 \%$ & $0 \%$ & $0 \%$ & 0.884 \\
SWE & Protestant & $87 \%$ & $0 \%$ & $0 \%$ & $0 \%$ & 0.757 \\
CHE & Catholic & $26.90 \%$ & $38.70 \%$ & $4.90 \%$ & $0 \%$ & 0.225 \\
UK & Catholic & $0 \%$ & $59.50 \%$ & $4.40 \%$ & $0 \%$ & 0.356 \\
US & Protestant & $51.30 \%$ & $23.90 \%$ & $0.60 \%$ & $0.70 \%$ & 0.320 \\
\hline
\end{tabular}


Table 4 The estimated housing supply elasticities of 18 OECD countries proposed by Caldera and Johansson (2013)

\begin{tabular}{llllllllll}
\hline Countries & AUS & BEL & CAN & DEN & FIN & FRA & GER & IRL & ITA \\
SupE & 0.528 & 0.315 & 1.187 & 1.206 & 0.988 & 0.363 & 0.428 & 0.631 & 0.258 \\
Countries & JPN & NLD & NZL & NOR & ESP & SWE & CHE & UK & US \\
SupE & 0.993 & 0.186 & 0.705 & 0.486 & 0.452 & 1.381 & 0.146 & 0.395 & 2.014 \\
\hline
\end{tabular}

\section{Results of hypothesis 2}

To test Hypothesis 2, we examine the interaction between the frequency of media coverage matrix with the cultural similarity matrices. Table 7 shows that the main effect and interaction effect of the cultural channel are significantly positive and robust across the three cultural similarity indices besides API, which corroborates that the cultural channel has a distinct effect on international housing price linkages under conditions of higher information dissemination efficiency. Hence, it supports Hypothesis 2. Nevertheless, the other spatial weight matrices are significantly negative to housing prices in affected countries, which is converse to traditional wisdom. As we expected, there exists a more severe multicollinearity problem should we introduces the interactive terms. In addition, the coefficients of other control variables are significant and consistent with our expectations.

\section{Results of hypothesis 3}

To verify Hypothesis 3, we produce an interaction term by creating interaction between the religious Herfindal indices and the cultural similarity matrices. Table 8 shows that all the interaction terms of the Herfindal indices with the cultural similarity matrices are significantly positive and robust, while only the main effects of Dyen and WF1 are significantly positive. It is also evident that conduct conformity amplifies the international housing price linkage via culture. Hence, it supports Hypothesis 3. Similarly, due to severe multicollinearity problems, the other spatial weight matrices are negative or not significant to housing prices. Additionally, the results of other controlling variants are consistent with our expectations as well, which further shows that our results are robust.

\section{Results of hypothesis $4^{7}$}

To verify Hypothesis 4, we cause the supply elasticity of a home country with cultural weighted housing prices to interact. Table 9 illustrates that the interaction of housing supply elasticity with four cultural similarity indices are significantly negative and robust, and that the spatial linkage parameters of culture are significantly positive, which supports Hypothesis 4. Thus, the housing supply elasticity of a country is able to mitigate international housing price contagion via the cultural channel. In other words, countries with greater housing price elasticity can resist external negative shocks, while countries with less housing price elasticities are susceptible to external contagion.

\section{Results of hypothesis 5}

To examine Hypothesis 5, we generate a spatial weight matrix of interaction between government participation indices of a country with culturally weighted house prices. 


\begin{tabular}{llllllllll}
\multicolumn{6}{l}{ Table 5 Indices of government participation in housing markets across } & 18 & OECD countries (GovP) \\
\hline Countries & AUS & BEL & CAN & DEN & FIN & FRA & GER & IRL & ITA \\
GovP & 0.31 & 0.25 & 0.44 & 0.25 & 0.29 & 0.31 & 0.25 & 0.25 & 0.25 \\
Countries & JPN & NLD & NZL & NOR & ESP & SWE & CHE & UK & US \\
GovP & 0.38 & 0.50 & 0.31 & 0.29 & 0.31 & 0.29 & 0.29 & 0.13 & 0.56 \\
\hline
\end{tabular}

Table 10 shows that the interaction terms are significantly negative and robust, and the spatial linkage parameters of the culture channel are also significantly positive. It corroborates Hypothesis 5. Hence, government participation in the housing market of a country can alleviate international housing price contagion via the cultural channel. In other words, those countries with more government participation can withstand external negative shocks, while those countries with less government participation are prone to external shocks.

\section{Conclusions and policy implications}

The literature on international housing market linkages has been growing since the subprime mortgage crisis. Unfortunately, the extant literature not only fails to examine the housing price contagion effect from the perspective of culture, but also neglects to examine the responses of affected countries to the country where the contagion originated. Thus, this paper sheds light on the influence of culture on international housing price co-movements and the responses of affected countries to contagious countries. Based on the databases of 18 OECD countries from 1970 to 2016, we draw the following conclusions.

Firstly, culture positively affects housing price co-movements. It is evident that similarities between countries' culture affects housing price spillover via information dissemination efficiency and investment conduct consistency. On the one hand, the more there is media coverage of the country where the contagion originates in the official language of other countries, the greater the housing market linkage is. Thus, the countries that share a language should pay great attention to negative and important news about housing price volatilities from other countries. Additionally, the greater the religious concentration in a countries and the greater the investment conduct conformity is, the greater the housing market co-movement is. Hence, countries with high levels of religious concentration are particularly subject to housing price contagion from other countries. In other words, we should be clearly conscious of the role of cultural factors in housing price co-movements, particularly for country pairs with higher levels of cultural similarity.

Secondly, housing market conditions affect housing price contagion effects. The interaction effects of domestic housing supply elasticity with the housing prices of countries where the contagion originates weighted by cultural similarities are negative, which indicates that housing supply elasticity could alleviate housing price contagion via the culture channel. For this reason, housing prices are more susceptible to external shocks in countries with less housing supply elasticity. Hence, the relevant countries can consider deregulating land zoning and accelerating the housing permit process to make the housing supply more resilient to abate housing price contagion effects.

Finally, government participation affects housing price contagion effects. The interaction effects of government participation indices with housing prices of countries 


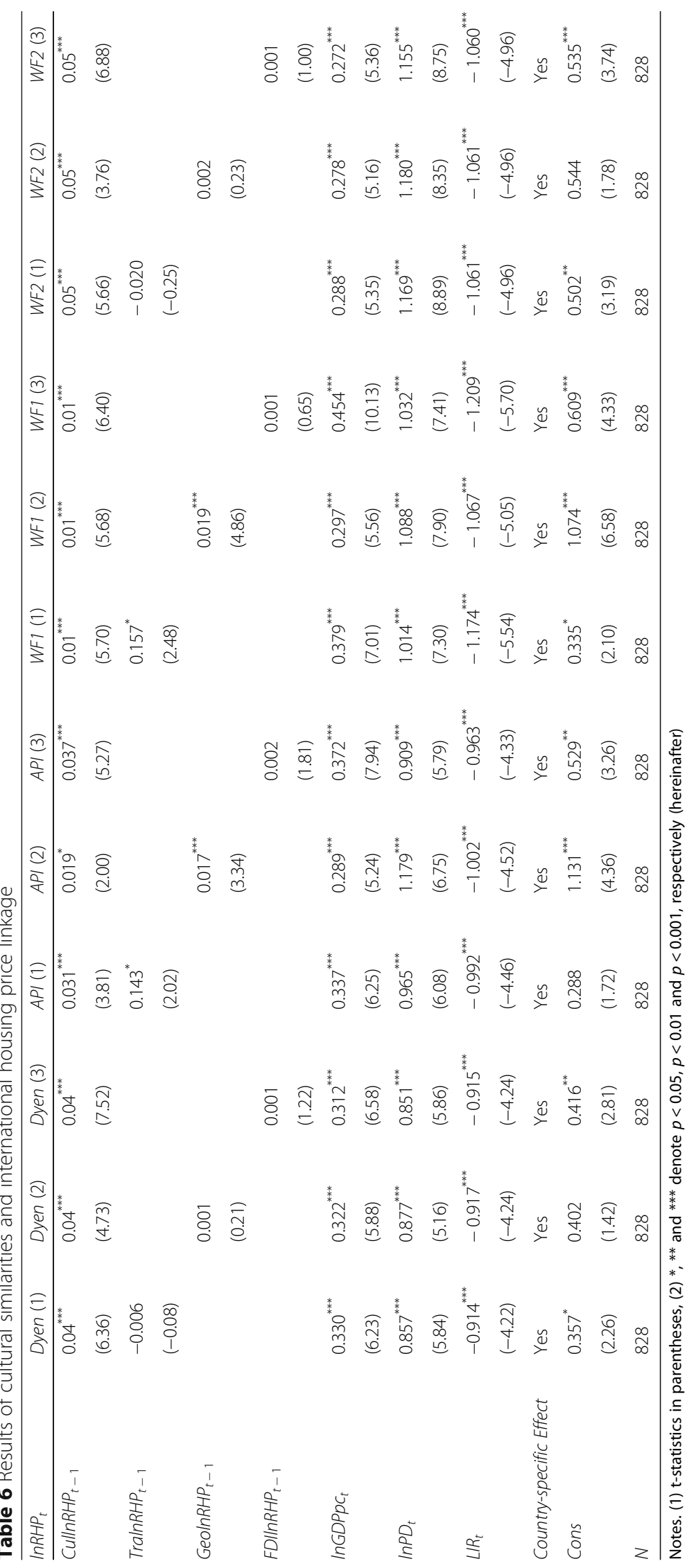




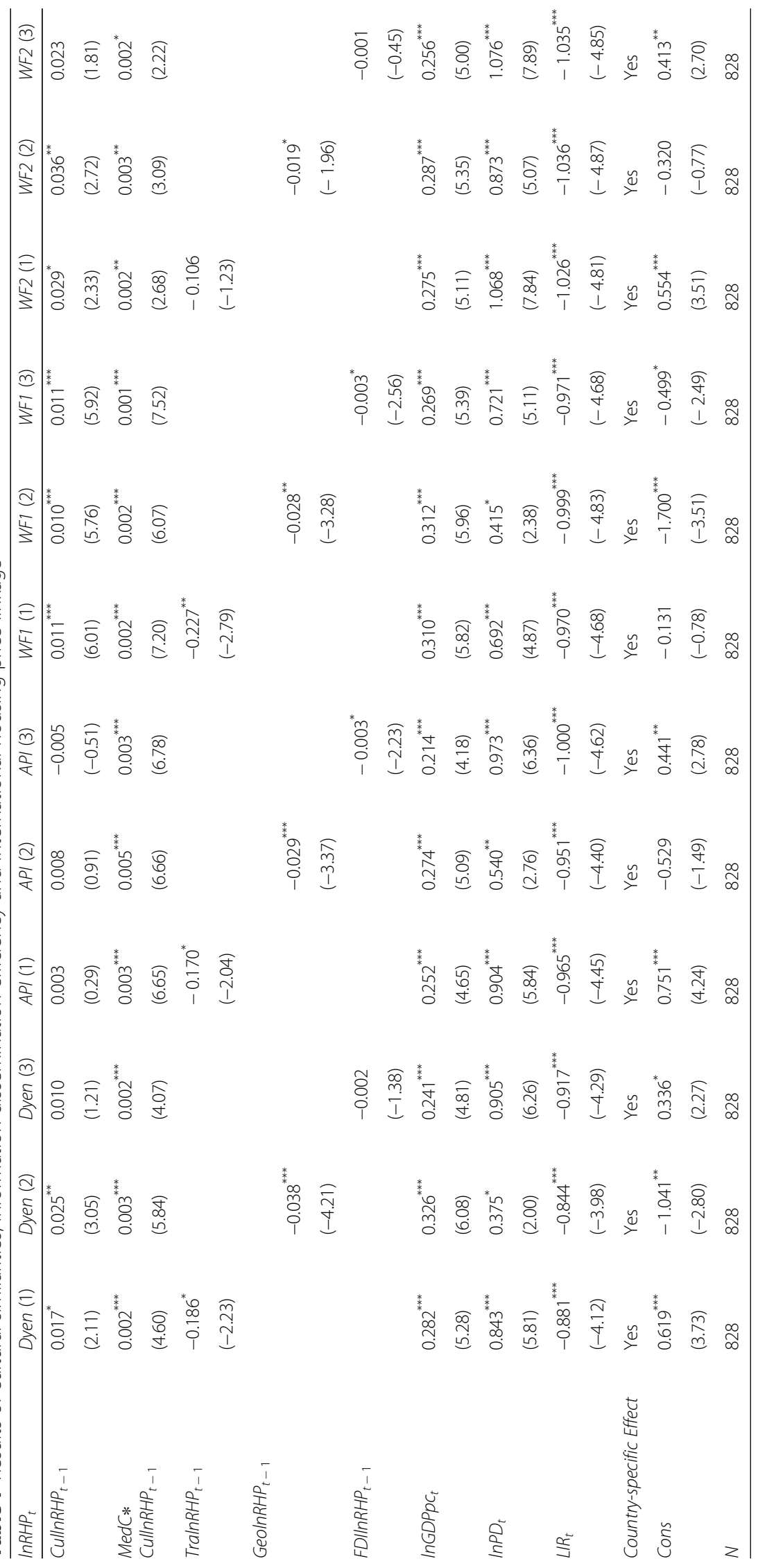




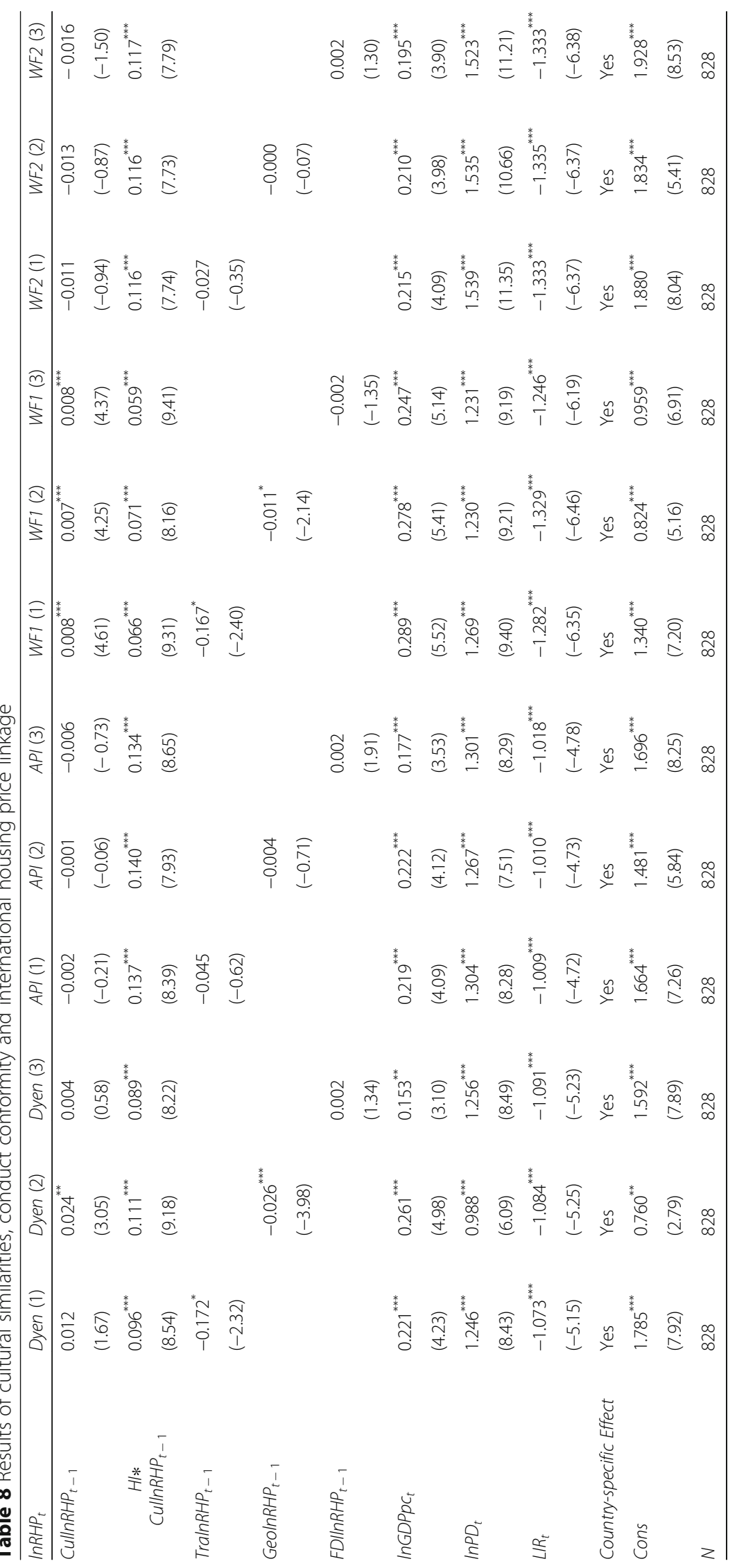




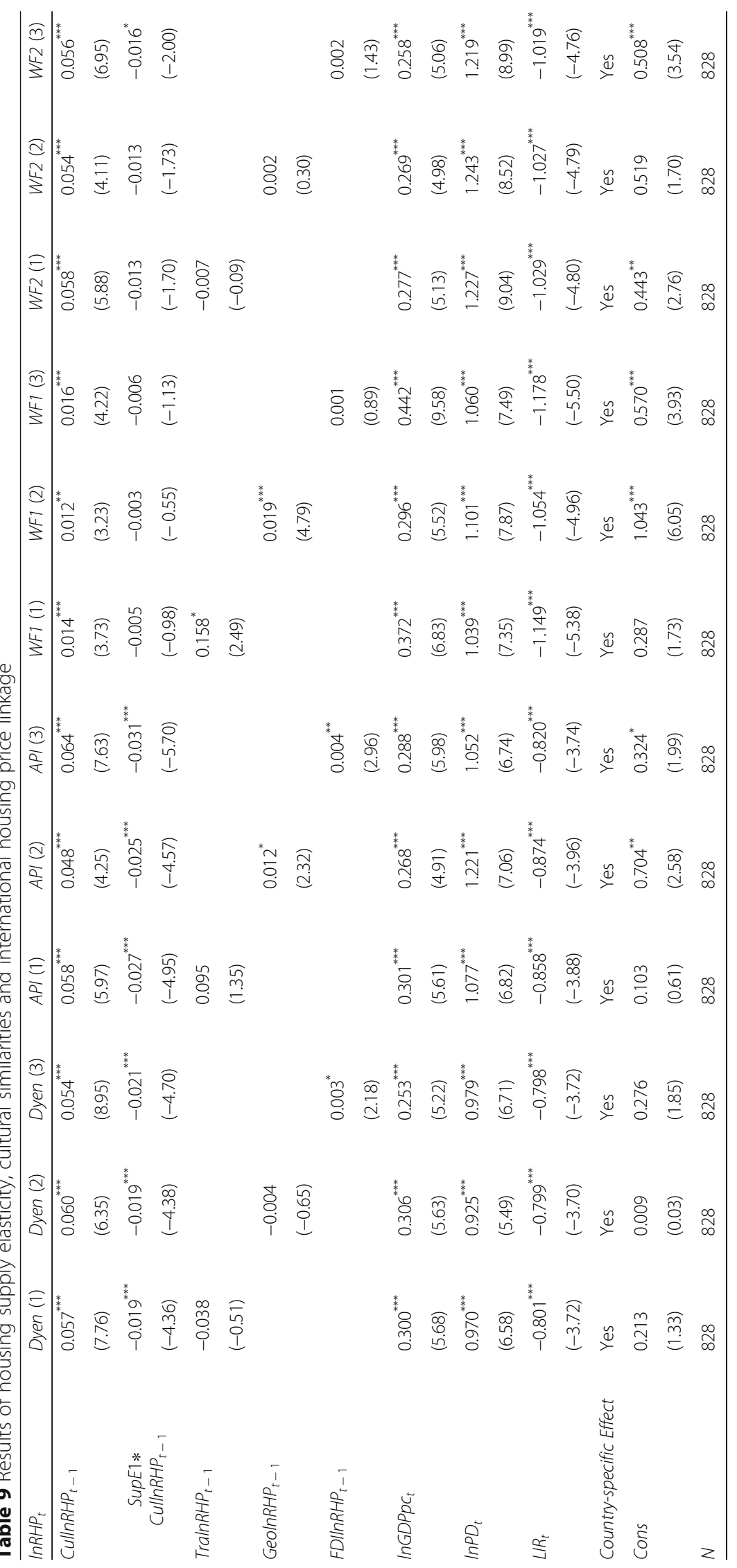




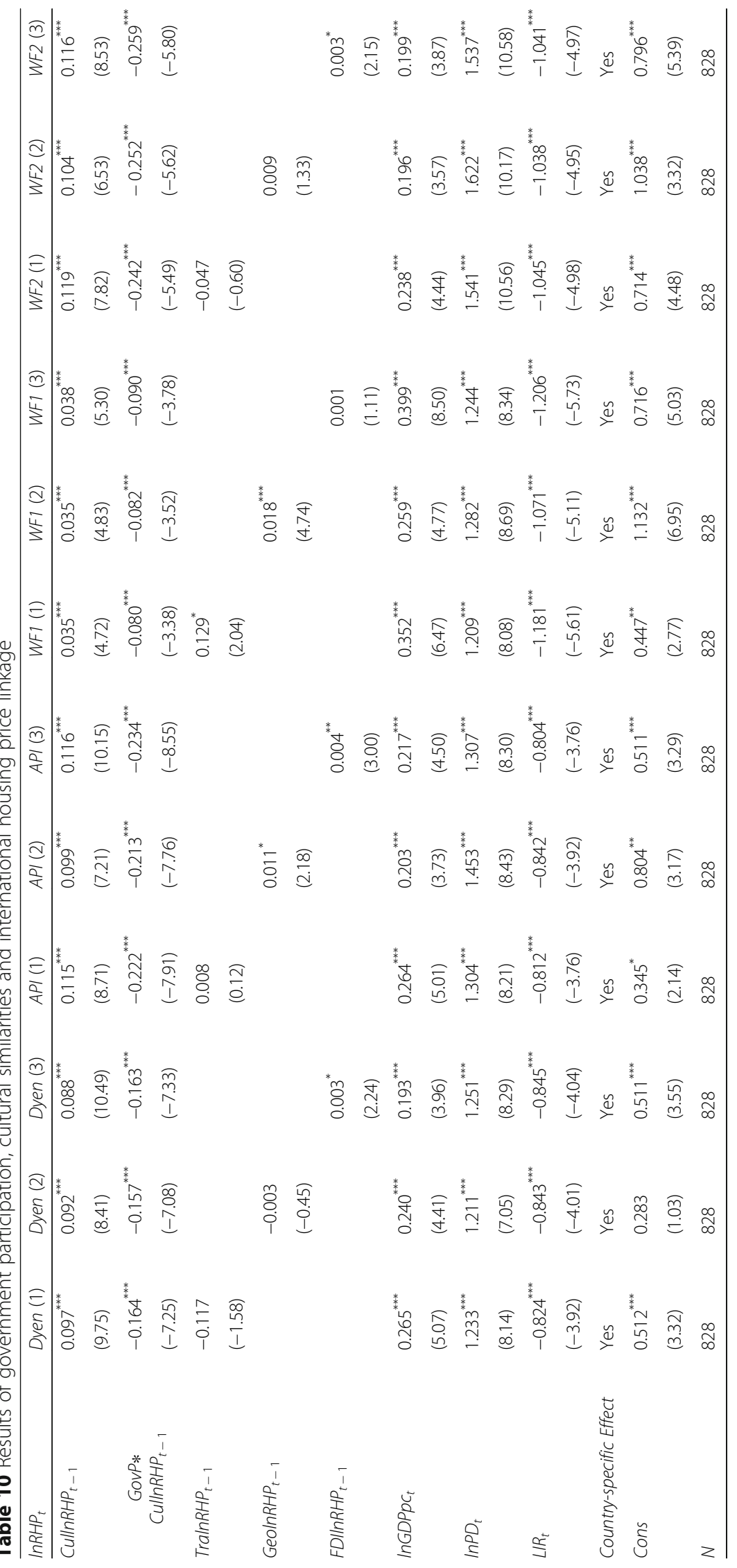


weighted by cultural similarity are negative, which implies that government participation could mitigate housing price contagion via the cultural channel as well. Consequently, housing prices are more exposed to external shocks in countries with less government participation. To prevent external housing price shocks, countries should carefully design their social housing polices and tax incentives, encourage more agencies to support liquidity in the housing market to prevent market failure and the absence of public intervention.

\section{Endnotes}

${ }^{1}$ Figures come from the OECD databases (see Data section). Additionally, to examine contagion effects, we selected six highly open countries: the US and Canada in North America, the UK and Germany in Europe, Japan in Asia and Australia in Oceania.

${ }^{2}$ According to the referee's suggestions, we construct the matrix of overall immigrants from a country of origin to overall population ratio in a destination country and its interaction with the real housing price matrix to capture the effects of immigration upon international housing price co-movements. Unfortunately, the results are either not significant or statistically negative. Hence, the results are not reported, but available upon request.

${ }^{3}$ If countries $a$ and $b$ are the same country, then $K S_{a b}=0$, we treat $1 / K S_{a b}$ as zero. Indeed, if $1 / K S_{a b}$ is taken as spatial weights, the diagonal elements are defined to zero to eliminate domestic housing price impacts.

${ }^{4}$ To address endogeneity issues, we apply the lagged spatial weighted housing price matrix instead of the current spatial weighted housing price matrix.

${ }^{5}$ The Chow-test results are available upon request.

${ }^{6}$ Due to space considerations, the unit root tests and co-integration tests are available upon request.

${ }^{7}$ We also utilize the reciprocal of days to obtain a building permit to conduct robustness check. The results of the robustness check indicates that the baseline results are robust. To save space, we do not report the results of robustness check, but it is available upon request.

\section{Abbreviations}

ABX: Asset-backed Securities; AUS: Australia; BEL: Belgium; CAN: Canada; CDO: Collateralized Debt Obligation; CEPII: The Center for Prospective Studies and International Information; CHE: Switzerland; DEN: Denmark; ESP: Spain; FDI: Foreign Direct Investment; FIN: Finland; FRA: France; GDP: Gross Domestic Product; GER: Germany; IRL: Ireland; ITA: Italy; JPN: Japan; M\&A: Mergers and Acquisitions; NLD: Netherlands; NOR: Norway; NZL: New Zealand; OECD: Organization for Economic Co-operation and Development; REIT: Real Estate Investment Trusts; SAR: Spatial Autoregressive Model; SEM: Spatial Errors Model; SWE: Sweden; UK: The United Kingdom; US: The United States; WF: World Factbook

\section{Funding}

This research is funded by National Natural Science Foundation of China (Grant No.71373276).

Availability of data and materials

\begin{tabular}{lll}
\hline Variables & Definitions & Sources \\
\hline RHP & Real house price index & $\begin{array}{l}\text { OECD-Analytical House Prices } \\
\text { Indicators }\end{array}$ \\
Dyen & $\begin{array}{l}\text { The spatial weight matrix of linguistic proximity between country pairs } \\
\text { proposed by Dyen et al. (1992) }\end{array}$ & Dyen et al. (1992) \\
API & $\begin{array}{l}\text { The spatial weight matrix of linguistic proximity between country pairs } \\
\text { proposed by Adsera and Pytlikova (2015) }\end{array}$ & Adsera and Pytlikova (2015)
\end{tabular}




\begin{tabular}{|c|c|c|}
\hline Variables & Definitions & Sources \\
\hline WF1 & $\begin{array}{l}\text { The spatial weight matrix of religious similarity between country pairs based } \\
\text { on KS law (Kogut and Singh 1988) }\end{array}$ & Raw data from WF \\
\hline WF2 & $\begin{array}{l}\text { The spatial weight matrix of the sum of the products of religious } \\
\text { concentration in country pairs }\end{array}$ & Raw data from WF \\
\hline Media & $\begin{array}{l}\text { The frequency of foreign media coverage in the official language of a } \\
\text { country }\end{array}$ & $\begin{array}{l}\text { Raw data from ABYZ New } \\
\text { Links }\end{array}$ \\
\hline HI & $\begin{array}{l}\text { The religious Herfindal index measured by the sum of the squares of the } \\
\text { religious shares in a home country }\end{array}$ & Raw data from WF \\
\hline Tra & $\begin{array}{l}\text { The spatial weight matrix of trade share measured by the proportion of } \\
\text { bilateral trade to the total trade volume of a home country }\end{array}$ & $\begin{array}{l}\text { Raw data from OECD- } \\
\text { International Trade }\end{array}$ \\
\hline Geo & The spatial weight matrix of relative geographic proximity & Raw data from CEPII \\
\hline Mig & $\begin{array}{l}\text { The spatial weight matrix of immigration share measured by the ratio of } \\
\text { immigration between country pairs to the total immigration of a country }\end{array}$ & $\begin{array}{l}\text { Raw data from OECD National } \\
\text { Accounts }\end{array}$ \\
\hline$F D l$ & $\begin{array}{l}\text { The spatial weight matrix of the minimum openness index of real estate } \\
\text { FDI. }\end{array}$ & $\begin{array}{l}\text { Raw data from OECD- } \\
\text { Globalization }\end{array}$ \\
\hline SupEla1 & The estimated housing supply elasticity & $\begin{array}{l}\text { Data from Caldera and } \\
\text { Johansson (2013) }\end{array}$ \\
\hline SupEla2 & The reciprocal of days to obtain a building permit & $\begin{array}{l}\text { Data from World Bank Doing } \\
\text { Business (2009) }\end{array}$ \\
\hline GovP & The index of government participation in the housing market & Data from IMF \\
\hline GDPpC & Gross domestic product per capita & $\begin{array}{l}\text { Raw data from OECD National } \\
\text { Accounts }\end{array}$ \\
\hline$L \mathbb{R}$ & Long-term interest rate & $\begin{array}{l}\text { Raw data from OECD National } \\
\text { Accounts }\end{array}$ \\
\hline$P D$ & Population density & $\begin{array}{l}\text { Raw data from OECD National } \\
\text { Accounts }\end{array}$ \\
\hline
\end{tabular}

\section{Authors' contributions}

We declare that all the authors have the equal contribution in this paper, while WK is a corresponding author. All authors read and approved the final manuscript.

\section{Competing interests}

The authors declare that they have no competing interests.

\section{Publisher's Note}

Springer Nature remains neutral with regard to jurisdictional claims in published maps and institutional affiliations.

\section{Received: 1 September 2017 Accepted: 26 April 2018}

Published online: 09 May 2018

\section{References}

Adhikari, B. K., \& Agrawal, A. (2016). Religion, gambling attitudes and corporate innovation. Journal of Corporate Finance, 37, 229-248.

Adsera, A., \& Pytlikova, M. (2015). The role of language in shaping international migration. The Economic Journal, 125(586), F49-F81.

Ahern, K. R., Daminelli, D., \& Fracassi, C. (2015). Lost in translation? The effect of cultural values on mergers around the world. Journal of Financial Economics, 117(1), 165-189.

Andrews, D., Sanchez, A. C., \& Johansson, A. (2011). Housing markets and structural policies in OECD countries. OECD Economic Department Working Papers, No.836, OECD Publishing, Paris. http://dx.doi.org/10.1787/5kgk8t2k9vf3-en.

Ang, J. S., Cheng, Y., \& Wu, C. (2015). Trust, investment, and business contracting. Journal of Financial and Quantitative Analysis, 50(3), 569-595.

Asgharian, H., Hess, W., \& Liu, L. (2013). A spatial analysis of international stock market linkages. Journal of Banking \& Finance, 37(12), 4738-4754.

Ballester, L., Casu, B., \& González-Urteaga, A. (2016). Bank fragility and contagion: Evidence from the bank CDS market. Journal of Empirical Finance, 38, 394-416. 
Beine, M., Cosma, A., \& Vermeulen, R. (2010). The dark side of global integration: Increasing tail dependence. Journal of Banking \& Finance, 34(1), 184-192.

Bekaert, G., Harvey, C. R., Lundblad, C. T., \& Siegel, S. (2011). What segments equity markets? The Review of Financial Studies, 24(12), 3841-3890.

Boubakri, N., \& Saffar, W. (2016). Culture and externally financed firm growth. Journal of Corporate Finance, 41, 502-520.

Brady, R. R. (2014). The spatial diffusion of regional housing prices across US states. Regional Science and Urban Economics, 46, 150-166.

Brown, P., \& Mitchell, J. (2008). Culture and stock price clustering: Evidence from the peoples' republic of China. PacificBasin Finance Journal, 16(1), 95-120.

Busse, J. A., \& Green, T. C. (2002). Market efficiency in real time. Journal of Financial Economics, 65(3), 415-437.

Caldera, A., \& Johansson, A. (2013). The price responsiveness of housing supply in OECD countries. Journal of Housing Economics, 22(3), 231-249.

Carstensen, K., Hülsewig, O., \& Wollmershäuser, T. (2009). Monetary policy transmission and house prices: European cross-country evidence.

Case, K. E., \& Shiller, R. J. (1989). The efficiency of the market for single-family homes. American Economic Review, 79, 125-137.

Catao, L., \& Timmermann, A. (2010). Volatility regimes and global equity market returns. In T. Bollerslev, J. Russell, \& M. Watson (Eds.), Volatility and time series econometrics: Essays in honour of Robert Engle (pp. 257-295). Oxford: Oxford University Press.

Cesa-Bianchi, A. (2013). Housing cycles and macroeconomic fluctuations: A global perspective. Journal of International Money and Finance, 37, 215-238.

Cesa-Bianchi, A., Cespedes, L. F., \& Rebucci, A. (2015). Global liquidity, house prices, and the macroeconomy: Evidence from advanced and emerging economies. Journal of Money, Credit and Banking, 47(S1), 301-335.

Chakrabarti, R., Gupta-Mukherjee, S., \& Jayaraman, N. (2009). Mars-Venus marriages: Culture and cross-border M\&a. Journal of International Business Studies, 40(2), 216-236

Chen, P. F., Chien, M. S., \& Lee, C. C. (2011). Dynamic modeling of regional house price diffusion in Taiwan. Journal of Housing Economics, 20(4), 315-332.

Chudik, A., \& Fratzscher, M. (2011). Identifying the global transmission of the 2007-2009 financial crisis in a GVAR model. European Economic Review, 55(3), 325-339.

Chui, A. C., Kwok, C. C., \& Zhou, G. S. (2016). National culture and the cost of debt. Journal of Banking \& Finance, 69, 1-19.

Chui, A. C., Titman, S., \& Wei, K. J. (2010). Individualism and momentum around the world. The Journal of Finance, 65(1), 361-392.

Clapp, J. M., Dolde, W., \& Tirtiroglu, D. (1995). Imperfect information and investor inferences from housing price dynamics. Real Estate Economics, 23(3), 239-269.

Cohen, J. P., loannides, Y. M., \& Thanapisitikul, W. W. (2016). Spatial effects and house price dynamics in the USA. Journal of Housing Economics, 31, 1-13.

Cotter, J., Gabriel, S. A., \& Roll, R. (2011). Integration and contagion in US housing markets. Available at SSRN: https:// ssrn.com/abstract=2017793 or https://doi.org/10.2139/ssrn.2017793.

Dees, S., Mauro, F. D., Pesaran, M. H., \& Smith, L. V. (2007). Exploring the international linkages of the euro area: A global VAR analysis. Journal of Applied Econometrics, 22(1), 1-38.

Diaz, J. D. (2000). Religion and gambling in sin-city: A statistical analysis of the relationship between religion and gambling patterns in Las Vegas residents. The Social Science Journal, 37(3), 453-458.

Dyen, I., Kruskal, J. B., \& Black, P. (1992). An Indoeuropean classification: A lexicostatistical experiment. Transactions of the American Philosophical Society, 82(5), 3-132.

Eickmeier, S., Gambacorta, L., \& Hofmann, B. (2014). Understanding global liquidity. European Economic Review, 68, 1-18.

Eickmeier, S., \& Ng, T. (2015). How do US credit supply shocks propagate internationally? A GVAR approach. European Economic Review, 74, 128-145.

Engsted, T., \& Pedersen, T. Q. (2014). Housing market volatility in the OECD area: Evidence from VAR based return decompositions. Journal of Macroeconomics, 42, 91-103.

Eun, C. S., Wang, L., \& Xiao, S. C. (2015). Culture and R 2. Journal of Financial Economics, 115(2), 283-303.

Ferreira, F., \& Gyourko, J. (2012). Heterogeneity in neighborhood-level price growth in the United States, 1993-2009. The American Economic Review, 102(3), 134-140.

Fischer, A. M. (2012). Immigrant language barriers and house prices. Regional Science and Urban Economics, 42(3), 389-395.

Grinblatt, M., \& Keloharju, M. (2001). How distance, language, and culture influence stockholdings and trades. The Journal of Finance, 56(3), 1053-1073.

Guiso, L., Sapienza, P., \& Zingales, L. (2003). People's opium? Religion and economic attitudes. Journal of Monetary Economics, 50(1), 225-282

Gupta, R., André, C., \& Gil-Alana, L. (2014). Comovement in euro area housing prices: A fractional cointegration approach. Urban Studies, 52(16), 3123-3143.

Gyourko, J. (2009). Housing supply. Annual Review Economics, 1(1), 295-318.

Harding, J. P., Rosenblatt, E., \& Yao, V. W. (2009). The contagion effect of foreclosed properties. Journal of Urban Economics, 66(3), 164-178.

Harter-Dreiman, M. (2004). Drawing inferences about housing supply elasticity from house price responses to income shocks. Journal of Urban Economics, 55(2), 316-337.

Hau, H., \& Lai, S. (2017). The role of equity funds in the financial crisis propagation. Review of Finance, 21(1), 77-108.

Hilary, G., \& Hui, K. W. (2009). Does religion matter in corporate decision making in America? Journal of Financial Economics, 93(3), 455-473.

Hirata, H., Kose, M. A., Otrok, C., \& Terrones, M. E. (2012). Global house price fluctuations: Synchronization and determinants (No. w18362). Working papers, No. 18362: http://www.nber.org/papers/w18362.

Hoesli, M., \& Reka, K. (2013). Volatility spillovers, comovements and contagion in securitized real estate markets. The Journal of Real Estate Finance and Economics, 47(1), 1-35. 
Hoesli, M., \& Reka, K. (2015). Contagion channels between real estate and financial markets. Real Estate Economics, 43(1), 101-138.

Hofstede, G. (1994). Management scientists are human. Management Science, 40(1), 4-13.

Holly, S., Pesaran, M. H., \& Yamagata, T. (2011). The spatial and temporal diffusion of house prices in the UK. Journal of Urban Economics, 69(1), 2-23.

Hong, H., \& Stein, J. C. (2007). Disagreement and the stock market. The Journal of Economic Perspectives, 21(2), 109-128.

Hu, J., Guo, F., \& Long, S. 胡军，郭峰，龙硕. 2013. 通胀惯性、通胀预期与我国通货膨胀的空间特征一一基于空间动 态面板模型 (Persistence, expectation and inflation spatial dynamics in China: A spatial dynamic panel model study). 经济学季刊 (China Economic Quarterly), 4: 57-80.

International Monetary Fund, 2011. Global financial stability report, April.

Jara, A., \& Romero, N. (2016). International synchronicity of housing prices. Revista de Análisis Económico - Economic Analysis Review, 31(2), 115-134. Available at SSRN: https://ssrn.com/abstract=298696

Kallberg, J. G., Liu, C. H., \& Pasquariello, P. (2014). On the price comovement of US residential real estate markets. Real Estate Economics, 42(1), 71-108.

Kogut, B., \& Singh, H. (1988). The effect of national culture on the choice of entry mode. Journal of International Business Studies, 19(3), 411-432.

Kumar, A., Page, J. K., \& Spalt, O. G. (2011). Religious beliefs, gambling attitudes, and financial market outcomes. Journal of Financial Economics, 102(3), 671-708.

Kurlat, P., \& Stroebel, J. (2015). Testing for information asymmetries in real estate markets. The Review of Financial Studies, 28(8), 2429-2461.

La Porta, R., Lopez-de-Silanes, F., Shleifer, A., \& Vishny, R. (1999). The quality of government. The Journal of Law Economics, and Organization, 15(1), 222-279.

Landier, A., Sraer, D., \& Thesmar, D. (2017). Banking integration and house price co-movement. Journal of Financial Economics, 125(1), 1-25.

Lane, P. R., \& Milesi-Ferretti, G. M. (2008). International investment patterns. The Review of Economics and Statistics, 90(3), 538-549.

Li, J., Tan, Q., \& Bai, J. 李婧, 谭清美, 白俊红. 2008. 中国区域创新生产的空间计量分析一一基于静态与动态空间面 板模型的实证研究 (A spatial analysis of regional innovation production in China: Based on static and dynamic spatial panel model). 管理世界 (Management World), 7: 43-55.

Liao, W. C., Zhao, D., Lim, L. P., \& Wong, G. K. M. (2015). Foreign liquidity to real estate market: Ripple effect and housing price dynamics. Urban Studies, 52(1), 138-158.

Lievenbrück, M., \& Schmid, T. (2014). Why do firms (not) hedge?-Novel evidence on cultural influence. Journal of Corporate Finance, 25, 92-106.

Longstaff, F. A. (2010). The subprime credit crisis and contagion in financial markets. Journal of Financial Economics, 97(3), 436-450.

Lucey, B. M., \& Zhang, Q. (2010). Does cultural distance matter in international stock market comovement? Evidence from emerging economies around the world. Emerging Markets Review, 11(1), 62-78.

Malpezzi, S. (1996). Housing prices, externalities, and regulation in US metropolitan areas. Journal of Housing Research, 1, 209-241.

Malpezzi, S., \& Maclennan, D. (2001). The long-run price elasticity of supply of new residential construction in the United States and the United Kingdom. Journal of Housing Economics, 10(3), 278-306.

Milcheva, S., \& Zhu, B. (2016). Bank integration and co-movements across housing markets. Journal of Banking \& Finance, 72, S148-S171.

Milunovich, G., \& Trück, S. (2013). Regional and global contagion in real estate investment trusts: The case of the financial crisis of 2007-2009. Journal of Property Investment \& Finance, 31(1), 53-77.

Monkkonen, P., Wong, K., \& Begley, J. (2012). Economic restructuring, urban growth, and short-term trading: The spatial dynamics of the Hong Kong housing market, 1992-2008. Regional Science and Urban Economics, 42(3), 396-406.

Nanda, A., \& Yeh, J. H. (2014). Spatio-temporal diffusion of residential land prices across Taipei regions. SpringerPlus, $3(1), 505$.

Oikarinen, E. (2004). The diffusion of housing price movements from center to surrounding areas. Journal of Housing Research, 15(1), 3-28.

Paciorek, A. (2013). Supply constraints and housing market dynamics. Journal of Urban Economics, 77, 11-26.

Paltalidis, N., Gounopoulos, D., Kizys, R., \& Koutelidakis, Y. (2015). Transmission channels of systemic risk and contagion in the European financial network. Journal of Banking \& Finance, 61, S36-S52.

Pollakowski, H. O., \& Ray, R. S. (1997). Housing price diffusion patterns at different aggregation levels: An examination of housing market efficiency. Journal of Housing Research, 8(1), 107-124.

Saiz, A. (2010). The geographic determinants of housing supply. The Quarterly Journal of Economics, 125(3), 1253-1296,

Sarkissian, S., \& Schill, M. J. (2004). The overseas listing decision: New evidence of proximity preference. The Review of Financial Studies, 17(3), 769-809.

Shiller, R. J. (1999). Human behavior and the efficiency of the financial system. Handbook of Macroeconomics, 1, 1305-1340.

Stulz, R. M., \& Williamson, R. (2003). Culture, openness, and finance. Journal of Financial Economics, 70(3), 313-349.

Teye, A. L., \& Ahelegbey, D. F. (2017). Detecting spatial and temporal house price diffusion in the Netherlands: A Bayesian network approach. Regional Science and Urban Economics, 65, 56-64.

Thanos, S., Dubé, J., \& Legros, D. (2016). Putting time into space: The temporal coherence of spatial applications in the housing market. Regional Science and Urban Economics, 58, 78-88.

Vansteenkiste, I., \& Hiebert, P. (2011). Do house price developments spillover across euro area countries? Evidence from a global VAR. Journal of Housing Economics, 20(4), 299-314.

Wälti, S. (2011). Stock market synchronization and monetary integration. Journal of International Money and Finance, $30(1), 96-110$

Weber, Y., Shenkar, O., \& Raveh, A. (1996). National and corporate cultural fit in mergers/acquisitions: An exploratory study. Management Science, 42(8), 1215-1227. 
World Bank Doing Business (2009). http://www.doingbusiness.org.

Wu, J., \& Deng, Y. (2015). Intercity information diffusion and price discovery in housing markets: Evidence from Google searches. The Journal of Real Estate Finance and Economics, 50(3), 289-306.

Yu, N. 余南平. 2010. 金融危机下欧洲国家经济衰退原因比较分析一以欧洲不同住房模式、住房价格变化为视角 (A comparison of the causes of the economic recession in the European countries: A perspective of the housing models). 欧洲研究 (European Studies), 2: 59-78.

Yuan, Y. (2015). Market-wide attention, trading, and stock returns. Journal of Financial Economics, 116(3), 548-564.

Submit your manuscript to a SpringerOpen ${ }^{\circ}$ journal and benefit from:

- Convenient online submission

- Rigorous peer review

Open access: articles freely available online

- High visibility within the field

- Retaining the copyright to your article

Submit your next manuscript at $\gg$ springeropen.com 